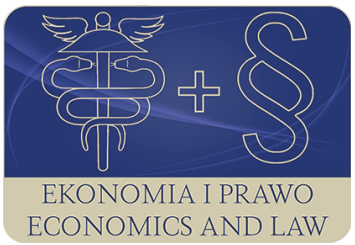

EKONOMIA I PRAWO. ECONOMICS AND LAW

Volume 18, Issue 1, March 2019

p-ISSN 1898-2255, e-ISSN 2392-1625

www.economicsandlaw.pl

ORIGINAL ARTICLE

received 27.02.2018; revised 24.07.2018; accepted 31.03.2019

Citation: Olejnik, Ł.W. (2019). Do coalition councillors grow rich faster? Quantitative analysis of asset declarations. Ekonomia i Prawo. Economics and Law, 18(1): 47-60. doi:10.12775/EiP.2019.004.

\title{
Do coalition councillors grow rich faster? Quantitative analysis of asset declarations
}

\author{
EUKASZ WIKTOR OLEJNIK \\ Warsaw School of Economics, Collegium of World Economy, Department of Economics II, \\ ul. Rakowiecka 24, 02-554 Warszawa, Poland \\ National Bank of Poland, ul. Świętokrzyska 11/21, 00-919 Warszawa, Poland \\ $\square$ lukasz.olejnik93@gmail.com \\ orcid.org/0000-0002-4250-961X
}

\begin{abstract}
Motivation: To study factors affecting changes in the wealth of people performing the functions of members of voivodeship assemblies.

Aim: To fill the existing research gap by conducting a quantitative analysis of data collected from asset declarations of all councillors of voivodeship assemblies in Poland from the 2010-2014 term, in particular an analysis of declared assets.

Results: The analysis of data clearly indicates that councillors belonging to the coalition ruling a given assembly in a given term accumulate wealth faster that opposition councillors. More detailed results also imply that the results cannot be explained by differences in sex, age or place of work between councillors of the specific political parties. The reason of the higher pace of growth of assets of coalition councillors may be their access to official positions in the public sector or having well-paid jobs.
\end{abstract}

Keywords: political economics; asset declarations; rent-seeking; office-seeking JEL: D72; D73; R50

\section{Introduction}

The theme of asset declarations submitted by people performing public functions is constantly present in the media, because their content may illustrate various phenomena which public activities entail. Significant changes in the wealth 
of people submitting asset declarations are often the subject of media speculation in terms of harmful connections between politicians and the world of business; they may also constitute grounds for initiating investigations on the suspicion of potential corruption. Asset declarations are a valuable source for researchers, too, as they allow studying the profile of people involved in public activities, their motivations, and potential abuse of power. There has been a lot of qualitative and case-study research done in the scope of assets of politicians; however, there is still a gap in the field in the form of a lack of an overview quantitative study carried out on a group of all voivodeship assembly councillors of a single term.

This article is an attempt to fill this gap. The data were collected from asset declarations of all councillors of voivodeship assemblies in the 2010-2014 term. The data collected related to the sex, profession, assets, and source of income of 469 councillors, while information from the State Election Commission and articles from the media served as a basis for identifying their political parties and the fact of being a member of coalition or opposition in a given voivodeship assembly. The obtained data allowed creating an econometric model, aimed at studying the pace of changes in the size of assets of both coalition and opposition councillors. Also, the study includes a robustness analysis of results carried out by testing hypotheses about the effect of the political party, age, sex, or current place of work on the pace of wealth growth. In all cases, variables describing the fact of belonging to the coalition proved significant and robust in relation to changes in model specification and elimination of outliers.

The rest of this article is organised as follows: section 2 presents a review of literature about existing theories in the scope of political economics, and a review of empirical studies on the subject in question. section 3 provides a description of the institutional background pertaining to the performance of the function of a councillor and asset declarations, as well as to data which served as a basis for creating the model described in section 4 . section 5 discusses the obtained results and their possible interpretations. Conclusions are contained in section 6 .

\section{Literature review}

The issue of pecuniary benefits connected with the exercise of public authority is a subject of research in economic studies, like the structure of incentive experienced by political agents. According to the public choice theory, agents whose conduct is rational aim at maximising their benefits under existing institutional constraints and make decisions as a result of a comparison of the expected returns of alternative choices (Downs, 1957, pp. 135-150).

The literature describing the process of shaping careers of election candidates and actual political agents is dominated by an approach assuming their complete rationality. The study of Osborne and Slivinsky (1993, pp. 65-96), presents a model of political competition against citizen-candidates with sin- 
gle-peaked preferences, who decide to run in an election based on the existing political configuration: it is costly to stand as a candidate; and if there is no candidate with appropriately similar views to citizens, some of them may decide to become candidates themselves and be elected by other citizens.

Caselli and Morelli (2004, pp. 759-782), offer a slightly different approach. In their model, candidates compete with each other under two traits - competences and honesty; and voters choose between a mix of honesty and competence. Less competent citizens have stronger incentive to stand as a candidate, because this way they gain an opportunity to achieve higher earnings, otherwise impossible for them to obtain on the labour market. Due to endogeneity and negative externalities in the process of shaping of the political scene, this can lead to a non-optimal equilibrium, with competent persons being superseded from the political scene.

In their work, Diermeier et al. (2003, pp. 347-373), present a model of a career of a congressman, who makes a decision to run in an election based on an analysis of opportunity cost and possibilities to earn money outside the Congress. After the end of term, the congressman chooses between a career in the public and private sectors, and empirical data suggest that his experience from work in the Congress is bound to significantly increase his earnings. The higher pace of growth of congressmen' assets was also confirmed for period of American Civil War (1861-1865). Both opposition and ruling congressmen grew rich faster during war they waged (Querubin \& Snyder, 2013, pp. 409-450).

Source literature also provides many other empirical analyses of members of parliaments and their earnings. Eggers and Heinmueller (2009, pp. 513533), used results of elections to the British parliament, data from probates, universities, parliament archives and other sources to create a data base of British members of parliament. This allowed estimating profits resulting from being a member of the parliament with the use of matching methods and regression discontinuity design (RDD). The fact of being an MP had a significant effect on the pace of accumulation of wealth by candidates from the Conservative Party, which was notably slower in the case of Labour Party deputies.

An analysis of earning of the Bundestag MPs can be found in the next work (Peichl et al., 2011, pp. 653-676). Based on data about earnings of MPs, they analysed the wage gap between politicians and people performing executive positions. Having conducted a series of analyses, the authors estimate that MPs earn 35-65\% more than other people with similar competences; this difference, however, drops to null in case of top-level executives. Earnings of Bundestag MPs are also analysed in the work of Arnold (2013, pp. 1-30), which proves that higher earnings on account of outside jobs have a negative effect on the parliamentary activity of a person and lead to frequent absences during voting.

The research also covers the effect of MPs' earnings on their will to stand as candidates to parliaments (labour supply of politicians). The next work (Fisman et al., 2012, pp. 871-905), presents an analysis of the influence of the salary of members of the European Parliament on their will to stand as candidates 
to the EP, which demonstrates that the doubling of the salaries of eurodeputies increases the probability of them running for the office again by $23 \%$. An increase of the salary of MPs in Finland led to a growth in the number of female candidates with higher education in parliamentary elections (Kotakorpi \& Poutvaara, 2011, pp. 877-885). In turn, the introduction of a bonus for MPs in Turkey for interrupting their pre-political careers caused a drop in their parliamentary activity (Altindag, et al., 2017, pp. 1-52). Based on an analysis of governors' earnings in the US, Besley (2004, pp. 193-215), concludes that higher salaries of governors may lead to them being more congruent with voters' views.

In Poland, the period of self-governmental reform of 1998-1999 saw many studies concerning the functioning of voivodeship self-governments and assemblies. From the point of view of this work, the most interesting are studies on the process of selection, socio-economic and professional profiles of councillors as well as the civic effectiveness and institutional control of councillors. The aim of creating voivodeship assemblies was to decentralise power and provide local communities with more competences. From the very beginning, voivodeship assemblies have been dominated by political parties, mostly dependent on their respective central authorities (Nalewajko, 2011, pp. 7-22).

A detailed process and determinants of the creation of coalition in voivodeship assemblies of the four-year 2006-2010 term was analysed by Betkiewicz (2011, pp. 23-56). The author collected data about gender, education, occupation, and age of almost all councillors, and based on that, he concludes that the most similar in terms of age, education and sex in the 2006-2010 term were the councillors of the Civic Platform Party (Polish Platforma Obywatelska, hereinafter 'PO') and of the Law and Justice Party (Polish Prawo i Sprawiedliwość, hereinafter 'PiS'), who were significantly different from the Polish People's Party (Polish Polskie Stronnictwo Ludowe, hereinafter 'PSL') and the Social Democratic Alliance Party (Polish Sojusz Lewicy Demokratycznej, hereinafter 'SLD'). The only notable difference between the councillors of PiS and PO was the place of work, because PO councillors were employed more in the private sector, while PiS councillors in the public sector. In spite of existing similarities, in only one voivodeship (Świętokrzyskie) did PiS and PO establish a coalition. The author concludes that the most probable motive for establishing a coalition in voivodeship assemblies in the 2006-2010 term was striving for office-seeking or similarities between the programmes of PO and PSL.

In yet another study (Betkiewicz \& Jasiewicz-Betkiewicz, 2014, pp. 295325 ), authors studied the routes of careers within political parties of PO and PiS councillors and the process of creating their electoral registers. They conclude that local conditions and recognisability of candidates play an important role; and in the case of PiS, the position inside the party is of particular significance. Bolibrzuch (2011, pp. 58-78), studies the results of a questionnaire conducted among councillors of voivodeship assemblies. Particularly interesting is the fact that the councillors are quite strongly attached to their respective parties, 
to which they are generally loyal, and they question the honesty of councillors from other parties. In her study Pańków (2011, pp. 137-160), also indicates that most female councillors are convinced that there is no actual gender equality and that the significant participation of women in exercising authority in voivodeship assemblies is of particular importance.

All above-mentioned studies prove the soundness of researching changes in the assets of councillors of voivodeship assemblies in Poland. Salaries received by the ruling coalition and being a member of the same have a significant effect on financial stimuli experienced by politicians, as they may be the cause of moral hazard. A review of existing research indicates a gap in the form of a lack of a quantitative study of asset declarations of councillors; therefore, such study may notably expand knowledge about the functioning of self-governmental authorities in Poland.

\section{Data and institutional background}

Under the self-government reform of 1998 in Poland, lst January 1999 was the start of functioning of new units of local self-government. The reform created sixteen voivodeships, which were meant to encompass socially and economically consistent regions of the country. Since the beginning, there has been a duality in the scope of authority over voivodeships, because a part of competences were taken over by voivodes appointed by central authorities (Nalewajko, 2011, pp. 7-22). Other competences belong to voivodeship assemblies elected for four-year terms in general, equal, direct, secret, and proportional elections. First election to voivodeship assemblies was held in October 1998, and since then they have been held every four years.

The number of councillors in an assembly depends on the number of residents in a voivodeship, and amounts to $30,33,36,39,48$ or 51 councillors. In total, there are 561 councillors in all 16 voivodeship assemblies. In accordance with the Act on voivodeship self-government (1998), councillors elect a voivodeship marshall, vice-marshalls (two at most), and executive board. According to the said act, as part of their competences, they nurture Polish culture and tradition, develop and shape national consciousness, stimulate economic activity and combat unemployment, improve competitiveness and innovation in the region, shape spatial order, manage assets, perform infrastructure investments, adopt and implement the budget, support higher education etc. All councillors receive allowances on account of the performance of their functions regardless of political affiliation (in 2014, each councillor received remuneration of PLN 2649.69 a month).

In line with the Act on voivodeship self-government (1998), councillors of voivodeship assemblies are obliged to submit asset declarations, which are meant to serve as anti-corruption devices. Asset declarations must be submitted within two months from the start of a term; each year during the performance of the function of a councillor; and two months before the end of a term. In 
asset declarations, councillors must disclose the value of money held in PLN and foreign currencies, securities, real estate, farmsteads, shares in commercial companies with participation of voivodeship corporate entities, shares in other commercial companies, movable property with value over PLN 10,000, and the value of liabilities. In addition, councillors need to declare the amount of income on account of held securities, pursuing a business, farming, employment agreements and civil law contracts. Asset declarations of councillors are verified by tax administration; and in case they find any data to have been concealed or untrue, the declarations are verified by the police and other authorities. Concealing data or providing untrue data in an asset declaration is an offence (Criminal Code, 1997, Art. 233 Section 1) subject to a penalty of three years' imprisonment.

Asset declarations of voivodeship assemblies are published on the website of the Public Information Bulletin for at least six years from the submission (Act on access to public information, 2001, Art. 6 Section 2). In order to conduct a study of assets of councillors, asset declarations of all councillors of the 20102014 term were examined, and based on obtained information, a data base was created, serving as a basis for creating the model described in section 4 .

Variables wealth 2010 and wealth 2014 present an aggregated value of assets in a given year. It is a sum of money in PLN and foreign currencies, value of held real estate properties, farmsteads, securities, shares in companies, enterprises and movable properties with value over PLN 10,000. This sum was reduced by the value of liabilities in PLN and foreign currencies. Sums in foreign currencies were converted to PLN as per the exchange rate of the National Bank of Poland published on the last day of a given year (i.e. 31st December 2010 and 31st December 2014). In case of adjustments to asset declarations, values and information provided therein were taken into account.

The values of assets provided by councillors were not interfered with, all values were recognised as given. In asset declarations, councillors enter information about the private property or property held jointly with a spouse. There is no information about the division of property due to a divorce, information about received inheritance and inherited property, donations, or transfer of selected assets to a separate property of the spouse. It may be assumed that between 2010 and 2014 many councillors got married or divorced, inherited assets from relatives, donated a part of their assets to children, or transferred a part of assets from joint marital property to separate property of the spouse. Unfortunately, such changes cannot be reflected in the model due to lack of relevant information.

In case of movable property with value over PLN 10,000, councillors are obligated only to list elements of such property, without the requirement to state their value. If the value in asset declaration from a given year was provided, then it was included in the course of creation of variables wealth 2010 or wealth 2014; 'otherwise' was not included. To some extent, it distorts the obtained results, because ca. $75 \%$ of councillors entered at least one car without stating its 
value. In analysed declarations, councillors also entered such movable assets as motorcycles, boats, sail-boats, tractors, harvesters, farming machinery, book collections, pigs, jewellery, pure-bred horses, snow cannons, art collections, ski lifts, and patents. One councillor entered as an asset the fact that her family belonged to the nobility; another councillor entered as liability: 'PLN 9,500 of debt on a credit card, which my wife spent without my consent'. Councillors often added comments to their income item, e.g. one councillor, in the filed 'income from a farmstead', entered a number with a comment 'sadly, the currant did not produce fruit'.

Based on the names of councillors, a female dummy variable was created, which takes the value of 1 for women, and 0 otherwise. The farmer variable takes the value of 1 if at least $5 \%$ of income of a councillor came from farming, and 0 otherwise. In their asset declarations, councillors are obligated to enter the profession and obtained income; however, they do not have to provide the place of work, and can enter 'councillor' as their profession. In a majority of cases $(92.8 \%)$, in at least one asset declaration, councillors provided information which made it possible to identify their place of work. Based on this information, an SOC dummy variable was created, assuming the value of 1 if the councillor worked at a state-owned company, and 0 otherwise. Also a PS dummy variable was created, which takes the value of 1 for persons employed in the public sector (e.g. at hospital, school, public office), and 0 for persons employed outside the public sector, not employed at all or for persons with unidentified occupation.

561 councillors from nine committees were elected to voivodeship assemblies in the term of 2010-2014: Civic Platform (hereinafter 'PO'), Law and Justice (hereinafter 'PiS'), Polish People's Party (hereinafter 'PSL'), Social Democratic Alliance (hereinafter 'SLD'); and in single voivodeships: German Minority (hereinafter 'MN'), Silesian Autonomy Movement (Ruch Autonomii Śląska, hereinafter 'RAŚ'), KWW Rafała Dutkiewicza, National Self-Governmental Community (Krajowa Wspólnota Samorządowa) and Self-Government Association (Porozumienie Samorządowe). Councillors elected from registers of individual parties created coalitions, which was officially reported by representatives of their respective parties. Based on coalition agreements, voivodeship executive boards were selected, and all coalition parties retained their positions in boards until the end of the term. In the case of 12 voivodeships, it was a PO-PSL coalition; in Podkarpacie and Lower Silesian voivodeships it was PO-PSL-SLD coalition; in Opolskie voivodeship it was PO-PSL-SLD-MN coalition; and in Silesian voivodeship it was PO-PSL-RAŚ coalition. The coalition variable takes the value of 1 for councillors being members of coalition; 0 otherwise.

In 2010, 561 councillors were elected; however, 90 out of this figure did not complete their terms due to death, resignation, or being elected to the Polish Parliament (the Sejm) in 2011 parliamentary elections. In the case of further 2 councillors, asset declarations were removed from the websites of the Public In- 
formation Bulletin, and Marshall's Offices refused to make them public. Thus, the set of councillors was reduced to 469 observations. The descriptive statistics of variables are presented in table 1.

\section{Model}

The main aim of creating the model is to study the effect of being a coalition member on the pace of changes in the size of assets. In order to better match the model to obtained data, a decision was made to take logarithms for wealth 2010 and wealth 2014, because relative changes play the key role here. Coefficients of the following auto-regressive model (1) were estimated:

$$
\log \left(\text { wealth }_{i, 2014}\right)=\beta_{0}+\beta_{1} \cdot \log \left(\text { wealth }_{i, 2010}\right)+\delta \cdot \text { coalition }_{i}+\beta^{\prime} X_{i}+\varepsilon_{i},
$$

where:

wealth $_{i, 2010}$ and wealth $_{i, 2014}$ - the wealth of $i$-th MP in 2010 or 2014;

$\beta_{0}$ - constant;

$X$ - control variables;

$\delta$ - the treatment effect of being in coalition;

$\varepsilon_{i}$ - residual.

In the second model (2), the variable was divided into coalition individual parties: PO, PSL and other (assuming the value of 1 for members of SLD, $\mathrm{MN}$ and RAŚ in assembly coalitions, and 0 otherwise). For the sake of the robustness analysis, an estimation of model (3) was made, in which the number of items was reduced to $363.10 \%$ of the wealthiest and $10 \%$ of the poorest councillors (per assets declared in 2010) were removed from the observation set. In model (4), the set of control variables was expanded by dummy variables A.20-29, A.30-39, A.40-49 and A.50-59 assuming the value of 1 for persons aged 20-29, 30-39, 40-49, 50-59 in 2010 (respectively), and 0 otherwise. Information was obtained based on dates of birth entered in asset declarations. Coefficients of all four models were estimated using the ordinary least squares (OLS) method.

Results of the estimation are presented in table 2 and table 3.

\section{Results}

Results of the estimation clearly point to the fact that coalition councillors became richer at a quicker pace than opposition councillors. In all four cases, coalition variables or coalition parties variables are significant at each statistical significance level higher than zero. In model (1), (2) and (4), coefficients are similar. In case of model (1), the value 0.2597 means that coalition councillors grew richer by an additional $29.66 \%$ (because $\exp (0.2597) \approx 1.2966)$. In model (3) with the reduced number of observations, coalition councillors grew richer 23.22\% more quickly than opposition councillors; and in model (4) with age variables, coalition councillors grew richer $30.48 \%$ more quickly. In model 
(2), coefficients for party variables are similar. All this confirms the hypothesis of the quicker pace of growth of wealth of people in power.

In order to improve specifications of the models, they also included variables describing sex, place of work, and the fact of being a farmer. In all four models, the farmer variable proved significant. The fact of being a farmer significantly increased the pace of growth of wealth in the period 2010-2014, regardless whether a person was a member of coalition or opposition. However, it needs to be pointed out that farmer councillors are not typical Polish farmers. Analyses of asset declarations demonstrate that in most cases they own large farms (with area much bigger than the average area of a farmstead in a given voivodeship). They also declare the fact of owning a significant number of agricultural machines. To a small extent, the farmer variable is positively correlated with the PSL variable and negatively with the $P O$ variable (Pearson correlation coefficient of 0.27 and -0.16 , respectively).

In order to check the robustness of model (1), coefficients of model (3) were estimated, with an exclusion of $10 \%$ of the most and the least wealthy councillors. In this case, coalition councillors demonstrate a higher pace of growth of wealth than opposition councillors, although this pace is slightly lower and amounts to $23.22 \%$. One can see that among coalition and opposition councillors there is a group of the richest and poorest councillors, which distort the results.

Based on an analysis of the results of estimation of model (4), it can be concluded that age has little effect on the pace of accumulation of wealth. For persons in the range of 20-49 years, dummy variables are statistically insignificant; and in the 50-59 variable, the $p$-value is barely conclusive. Therefore, it cannot be stated that there is any significant pattern of accumulation of wealth in a life cycle. Furthermore, opposition and coalition councillors slightly differ in terms of age, as the average age of coalition councillors is 50.1 years, and 50.6 years for opposition councillors.

The very fact of a greater pace of growth of assets of coalition councillors than opposition councillors is clearly visible after analysing results of estimations of the models. However, a question emerges concerning the source of this phenomenon and the causes for which coalition councillors grow rich faster.

Is this caused by corruption? Obtained data do not allow confirming this fact; based on analysed declarations, it is impossible to prove any corrupt practices. The values of variables describing employment in the public sector and in stateowned companies are statistically insignificant and close to null, which contradicts the corruption hypothesis.

Is the higher pace of growth of wealth among coalition councillors caused by their access to positions in the public sector and state-owned companies? As in the previous case, the insignificance of SOC and PS variables contradicts such hypothesis. It needs to be noted that also opposition councillors (i.e. SLD councillors in 13 voivodeships, PiS councillors and others) often declared employment in the public sector or SOC. Public positions were found in self-governments at the communal, municipal, and county levels (mostly in self-governments ruled 
by PiS or SLD). The percentage of coalition councillors employed at SOC was $15.5 \%$, and was even higher in opposition councillors - $23.2 \%$. This contradicts the hypothesis of particularly significant effect of access to public positions among coalition councillors on the pace of growth of their assets.

Is this caused by the fact that coalition councillors are more resourceful in life, which contributes both to winning elections and the pace of becoming richer? This hypothesis is very difficult to confirm or refute, because there is no way to examine life resourcefulness based on asset declarations. The above-mentioned study by Betkiewicz (2011, pp. 23-56), demonstrates that PO and PiS councillors in the 2006-2010 term are similar to each other in terms of the structure of age and education. It can be reasonably assumed that the nature of both parties did not undergo any significant changes in the period of 2010-2014, and councillors from these two parties were still similar to each other in terms of the structure of age and education. The only piece of information allowing an attempt to assess the life situation is information about occupation or place of work of councillors (in case of $92.8 \%$ of councillors). Asset declarations reveal that among PO councillors there are many lawyers, doctors, entrepreneurs, and teachers; and among PiS, there are many pensioners, teachers, and farmers. Among SLD councillors, there are many chairpersons of trade unions, presidents of cooperatives, and entrepreneurs; whereas in PSL, there are many farmers, fire-fighters, foresters, and veterinarians. Perhaps the higher pace of changes in the assets of coalition councillors was influenced by their occupations, which were higher in demand on the market. However, this issue calls for much more thorough analyses.

\section{Conclusions}

The article presents the results of one of Poland's first quantitative studies of asset declarations submitted by persons performing public functions. Based on asset declarations of 469 councillors from the 2010-2014 term, a data-base was created, providing information about gender, age, occupation, political affiliation, and wealth of councillors from all voivodeship assemblies in Poland. This allowed an estimation of the effect of belonging to coalition on the pace of growth of assets of councillors. Based on results of estimation of econometric models, it can be reasonably stated that coalition councillors accumulated wealth faster than opposition councillors. Variables describing gender, age, and occupation of a councillor were in most cases statistically insignificant.

The cause of such pace of changes in the assets of coalition councillors is much less certain. There is no evidence of corruption, and the fact of being employed in the public sector or SOC did not have any significant effect on changes in the wealth of councillors either. The hypothesis of greater skills and resourcefulness of coalition councillors is impossible to verify. In order to create a professional profile of councillors of individual parties, further studies must be conducted. 


\section{References}

Altindag, D.T., Filiz, S.E., \& Tekin, E. (2017). Does it matter how and how much politicians are paid. NBER Working Paper Series, 23613. doi:10.3386/ w23613.

Arnold, F. (2013). German MPs' outside jobs and their repercussions on parliamentary effort. DIW Berlin Discussion Paper, 1340. doi:10.2139/ ssrn. 2387498.

Besley, T. (2004). Paying politicians: theory and evidence. Journal of the European Economic Association, 2(2-3). doi:10.1162/154247604323067925.

Betkiewicz, W. (2011). Determinanty składu koalicji w sejmikach wojewódzkich w 2010 roku. Cele programowe czy stanowiska w zarządach? In E. Nalewajko (Ed.), Radni sejmików wojewódzkich. Warszawa: ISP PAN.

Betkiewicz, W., \& Jasiewicz-Betkiewicz, A. (2014). Wielkomiejscy radni Platformy Obywatelskiej i Prawa i Sprawiedliwości na ścieżkach do stanowisk zajmowanych w kadencji 2006-2010. Politeja, 11(27). doi:10.12797/ Politeja.11.2014.27.15.

Bolibrzuch, P. (2011). Postawy, zachowania i stosunki wewnętrzne w sejmikach wojewódzkich. In E. Nalewajko (Ed.), Radni sejmików wojewódzkich. Warszawa: ISP PAN.

Caselli, F., \& Morelli, M. (2004). Bad politicians. Journal of Public Economics, 88(3-4). doi:10.1016/S0047-2727(03)00023-9.

Diermeier, D., Keane, M.P., \& Merlo, A.M. (2005). A political economy model of congressional careers. American Economic Review, 95(1). doi:10.1257/0002828053828464.

Downs, A. (1957). An economic theory of political action in a democracy. Journal of Political Economy, 65(2). doi:10.1086/257897.

Eggers, A.C., \& Hainmueller, J. (2009). MPs for sale? Estimating returns to office in postwar British politics. American Political Science Review, 103(4). doi:10.1017/S0003055409990190.

Fisman, R., Harmon, N.A., Kamenica, E., \& Munk, I. (2015). Labor supply of politicians. Journal of the European Economic Association, 13(5). doi:10.1111/ jeea.12141.

Kotakorpi, K., \& Poutvaara, P. (2011). Pay for politicians and candidate selection: an empirical analysis. Journal of Public Economics, 95(7-8). doi:10.1016/j. jpubeco.2010.11.005.

Nalewajko, E. (2011). Założenia, cele i konstrukcja samorządu wojewódzkiego. In E. Nalewajko (Ed.), Radni sejmików wojewódzkich. Warszawa: ISP PAN.

Osborne, M.J., \& Slivinski, A. (1996). A model of political competition with citizen-candidates. The Quarterly Journal of Economics, 111(1). doi:10.2307/2946658.

Pańków, I. (2011). Dyskryminacja czy równouprawnienie? „Kwestie kobiece” w opinii radnych sejmików wojewódzkich oraz w opinii publicznej. In E. Nalewajko (Ed.), Radni sejmików wojewódzkich. Warszawa: ISP PAN. 
Peichl, A., Pestel, N., \& Siegloch, S. (2011). The politicians' wage gap: insights from German members of parliament. Public Choice, 156(3-4). doi:10.1007/ s11127-012-9921-4.

Querubin, P., \& Snyder, J. (2013). The control of politicians in normal times and times of crisis: wealth accumulation by U.S. congressmen, 1850-1880. Quarterly Journal of Political Science, 8(4). doi:10.1561/100.00012104.

Ustawa z dnia 5 czerwca 1998 r. o samorządzie województwa [Act of 5 June 1998 on voivodeship self-government] (Dz.U. $1998 \mathrm{nr} 91$ poz. 576) (Poland).

Ustawa z dnia 6 czerwca 1997 r. Kodeks Karny [Act of 6 June 1997 Criminal Code] (Dz.U. $1997 \mathrm{nr} 88$ poz. 553) (Poland).

Ustawa z dnia 6 września $2001 \mathrm{r}$. o dostępie do informacji publicznej [Act of 6 September 2001 on access to public information] (Dz.U. $2001 \mathrm{nr} 112$ poz. 1198) (Poland).

\section{Acknowledgements}

Author contributions: author/authors has/have given an approval to the final version of the article.

Funding: this research was fully funded by the author.

Supplementary information: author acknowledge following people for help with the preparation of the article: Witold Jaśkiewicz, Maciej Pomykała and Tymon Słoczyński.

Disclaimer: The views expressed in this paper are those of the author and do not necessarily reflect opinions of the institutions to which they are affiliated. 


\section{Appendix}

Table 1.

Descriptive statistics

\begin{tabular}{lrrrr}
\hline \multicolumn{1}{c}{ Variable } & Maximum & Mean & Minimum & Standard deviation \\
\hline wealth 2010 (in thous.) & 22519.0 & 829.900 & -2780.80 & 1896.600 \\
wealth 2014 (in thous.) & 29200.0 & 1076.300 & -761.830 & 2673.400 \\
coalition & 1.0 & 0.606 & 0.00 & 0.489 \\
PO & 1.0 & 0.388 & 0.00 & 0.488 \\
PSL & 1.0 & 0.173 & 0.00 & 0.378 \\
other & 1.0 & 0.045 & 0.00 & 0.207 \\
female & 1.0 & 0.239 & 0.00 & 0.427 \\
farmer & 1.0 & 0.092 & 0.00 & 0.289 \\
public sector & 1.0 & 0.495 & 0.00 & 0.501 \\
SOC & 1.0 & 0.186 & 0.00 & 0.389 \\
\hline
\end{tabular}

Source: Own preparation.

Table 2.

Results of estimation of model (1) and model (2)

\begin{tabular}{|c|c|c|c|c|c|c|}
\hline \multirow{2}{*}{ Variable } & \multicolumn{3}{|c|}{$\begin{array}{c}\text { Model (1) } \\
\text { dependent variable: } \log (\text { wealth 2014) }\end{array}$} & \multicolumn{3}{|c|}{$\begin{array}{c}\text { Model (2) } \\
\text { dependent variable: } \log (\text { wealth 2014) }\end{array}$} \\
\hline & Coefficient & Std. error & $p$-value & Coefficient & Std. error & $p$-value \\
\hline constant & 1.5081 & 0.1440 & 0.0000 & 1.5006 & 0.1447 & 0.0000 \\
\hline $\log ($ wealth 2010) & 0.7621 & 0.0222 & 0.0000 & 0.7634 & 0.0223 & 0.0000 \\
\hline coalition & 0.2597 & 0.0519 & 0.0000 & - & - & - \\
\hline $\mathrm{PO}$ & - & - & - & 0.2411 & 0.0576 & 0.0000 \\
\hline PSL & - & - & - & 0.2908 & 0.0739 & 0.0000 \\
\hline other & - & - & - & 0.2994 & 0.0124 & 0.0161 \\
\hline female & -0.0744 & 0.0605 & 0.2194 & -0.0675 & 0.0613 & 0.2709 \\
\hline farmer & 0.3755 & 0.0887 & 0.0000 & 0.3594 & 0.0921 & 0.0001 \\
\hline public sector & -0.0700 & 0.0520 & 0.1789 & -0.0724 & 0.0522 & 0.1659 \\
\hline \multirow[t]{2}{*}{ SOC } & -0.0047 & 0.0649 & 0.9427 & -0.0032 & 0.0651 & 0.9613 \\
\hline & Statistics & & $p$-value & Statistics & & $p$-value \\
\hline number of observations & 469 & & - & 469 & & - \\
\hline $\mathrm{R}^{2}$-adjusted & 0.7731 & & - & 0.7734 & & - \\
\hline Wald test & 246.4213 & & 0.0000 & 184.2724 & & 0.0000 \\
\hline White test & 65.5860 & & 0.0000 & 77.5724 & & 0.0000 \\
\hline Ramsey RESET test & 19.7299 & & 0.0000 & 20.0411 & & 0.0000 \\
\hline Jarque-Bera test & 183.6000 & & 0.0000 & 180.444 & & 0.0000 \\
\hline
\end{tabular}

Source: Own preparation. 
Table 3.

Results of estimation of model (3) and model (4)

\begin{tabular}{|c|c|c|c|c|c|c|}
\hline \multirow[t]{2}{*}{ Variable } & \multicolumn{3}{|c|}{$\begin{array}{c}\text { Model (3) } \\
\text { dependent variable: } \log (\text { wealth 2014) }\end{array}$} & \multicolumn{3}{|c|}{$\begin{array}{c}\text { Model (4) } \\
\text { dependent variable: } \log (\text { wealth 2014) }\end{array}$} \\
\hline & Coefficient & Std. error & $p$-value & Coefficient & Std. error & $p$-value \\
\hline constant & 1.0683 & 0.2192 & 0.0000 & 1.5605 & 0.1549 & 0.0000 \\
\hline $\log ($ wealth 2010) & 0.8307 & 0.0361 & 0.0000 & 0.7490 & 0.0235 & 0.0000 \\
\hline coalition & 0.2088 & 0.0500 & 0.0000 & 0.2660 & 0.0518 & 0.0000 \\
\hline female & -0.1028 & 0.0579 & 0.0767 & -0.0895 & 0.0606 & 0.1409 \\
\hline farmer & 0.2903 & 0.0939 & 0.0021 & 0.3666 & 0.0890 & 0.0000 \\
\hline public sector & -0.0122 & 0.0497 & 0.8059 & -0.0649 & 0.0525 & 0.2177 \\
\hline SOC & -0.0244 & 0.0625 & 0.6969 & -0.0104 & 0.6500 & 0.8728 \\
\hline A. $20-29$ & - & - & - & -0.1568 & 0.2084 & 0.4521 \\
\hline A. $30-39$ & - & - & - & -0.0330 & 0.0837 & 0.6935 \\
\hline A.40-49 & - & - & - & -0.2221 & 0.0700 & 0.7513 \\
\hline \multirow[t]{2}{*}{ A.50-59 } & - & - & - & 0.1197 & 0.0653 & 0.0676 \\
\hline & Statistics & & $p$-value & Statistics & & $p$-value \\
\hline number of observations & 375 & & - & 469 & & - \\
\hline $\mathrm{R}^{2}$-adjusted & 0.6379 & & - & 0.7768 & & - \\
\hline Wald test & 106.2694 & & 0.0000 & 149.6496 & & 0.0000 \\
\hline White test & 24.2920 & & 0.3321 & 92.4052 & & 0.0001 \\
\hline Ramsey RESET test & 2.4644 & & 0.0865 & 22.7117 & & 0.0000 \\
\hline Jarque-Bera test & 161.4880 & & 0.0000 & 180.8360 & & 0.0000 \\
\hline
\end{tabular}

Source: Own preparation. 